\title{
The Importance of the Brain Neuro-Programming Technologies in National and Regional Security Strategies
}

\author{
Vasyl H. Fatkhutdinov \\ Doctor of Law, Associate Professor, Bila Tserkva National Agrarian University (Kyiv, \\ Ukraine) \\ E-mail: mfkoorg@gmail.com
}

\author{
Oleg Bazaluk \\ Doctor of Philosophical Sciences, Professor, Pereyaslav-Khmelnytsky Hryhoriy \\ Skovoroda State Pedagogical University (Kyiv, Ukraine) \\ E-mail: bazaluk@ukr.net \\ ORCID: 0000-0002-1623-419X
}

\begin{abstract}
The authors' understanding of neuro-programming is the result of the impact on the human brain of information and communication technology (including educational one), through which in the human brain the programs of manifestation in the ontogenesis of internal creative potentials are written. This article summarizes the history of the formation of key neuro-programming technologies of the human brain as well as proves that the changes in the society's worldview are caused by the possibilities and quality of neuro-programming technologies that society uses. Having influence over worldview stereotypes and behaviour set by the society, neuro-programming technologies essentially ensure the national security of any state and the peaceful coexistence of states in the regions and on the planet as a whole. Using historical and philosophical methods, methods of conceptualization, systematization, modeling, etc., the authors have come to the conclusion that the modern world lies in a confrontation of security strategies, in which neuro-programming technologies play a key role.
\end{abstract}

Keywords: technologies of neuro-programming, educational technologies, Plato, national security, human brain, the state

Received 15 June 2017; accepted 23 July 2017

Philosophy and Cosmology, Volume 20, 2018: 74-82

DOI: $10.29202 /$ phil-cosm/20/6

(C) Fatkhutdinov, Vasyl, 2018

(C) Bazaluk, Oleg, 2018 


\section{Introduction}

In the authors understanding, neuro-programming is the result of the impact on the human brain of information and communication technology (including educational one), through which in the human brain the programs of manifestation in the ontogenesis of internal creative potentials are written. We assert that the changes in the society's worldview are caused by the possibilities and quality of neuro-programming technologies that society uses.

Below, we consider the examples from the history of the theories of education in Antiquity and the Middle Ages, how representatives of Plato's line ${ }^{1}$ gradually discovered the possibilities of educational technology ${ }^{2}$ and regulated the formation of the society' worldview, in fact dealing with neuro-programming of generations.

\section{The technology of individual achievement of the cultural ideal based on knowledge obtained as a result of continuous self-improvement and self-development}

In the "Republic", Plato clearly defined his attitude towards education [Plato, 1994]. In education, Plato saw a new religion that had led the way into the newfound land of the soul. Vladimir Platonov formulated the purpose of Plato's theory of education as follows: “...the awakening in man a feeling of "taking care of himself," about his soul, about its communion with these lofty ideas that give a power to man over himself, affirming his "inner freedom" from subordination to any material needs or instincts up to the need for life itself" [Platonov, 2013: 80]. As Werner Jaeger noted, Plato initially considered education as a power that pursues the divine purpose, the idea of the Good to which the "best state" should strive [Jaeger, 1947]. That is why "Politeia" and "Paideia" occupy a central place in Plato's Republic.

Having proposed paideia as Socrates' new religion instead of anthropomorphic Gods who lost already their power in Ancient Greece, Plato singled out the highest stage of development in it - philosophy. In the Republic, Plato "raised philosophy in general to be the highest cultural force ${ }^{3}$ and considered philosophers as the high caste rulers who were capable of leading their people to the heights of the Divine. It should not be forgotten that in democratic Athens, where the power belonged to free demos (ancient Greek $\Delta \tilde{\eta} \mu \varsigma_{\varsigma}$ - "people"), and equality and freedom continued to be cult values, Plato preached the opposite idea - the most worthy rulers were philosophers that he showed: "as the highest type of Dionysiac man"; "...those for whom the truth is the spectacle of which they are enamored" [Plato, 1994: 255]; " “...who in each and every kind welcome the true being” [Plato, 1994: 261]; "We must accept as agreed this trait of the philosophical nature, that it is ever enamored of the kind of knowledge which reveals to them something of that essence which is eternal, and is not wandering between the two poles of generation and decay" [Plato, 1994: 263]; having in their character "the spirit of truthfulness, reluctance to admit falsehood in any form, the hatred of it and the love of truth" [Plato, 1994: 263]; etc. Most importantly that philosophers in the understanding of Plato, from birth, possessed the same kalokagathia ( $\kappa \alpha \lambda o ́ \varsigma \kappa \alpha ́ \gamma \alpha \theta$ ó $\varsigma$ ), that is, the highest ideal of spiritual perfection in the classical period of Greek culture.

${ }^{1}$ See [Bazaluk, 2017].

${ }^{2}$ That is, the main markers of neuro-programming and the process of neuro-programming were changed.

${ }^{3}$ See [Jaeger, 1947: 86].

${ }^{4}$ For example, Plato represented such an image of the philosopher in the "Feast" [Jaeger, 1947: 173]. 
Plato, following Socrates, tried to distance himself as much as possible from Greek Paideia, which had lost its authority and, accordingly, to protect philosophy that occupied a key place in his theory of education from rhetoric. In the "Republic", Plato built his paideiareligion on a completely new basis - knowledge, as the essence of a single virtue of man, his areté. ${ }^{5}$ Cicero did not understand and undeservedly condemned this important feature of Plato's education: “...he (Socrates) separated in his discussions the ability of thinking wisely, and speaking gracefully, though they are naturally united" [Cicero, 1860: III, 60]. He continued: "Hence arose that divorce as it were of the tongue from the heart, a division certainly absurd, useless, and reprehensible, that one class of persona should teach us to think, and another to speak, rightly" [Cicero, 1860: III, 61].

In the dialogue "De Oratore," written in 55 BC, Cicero wrote: "Wisdom without eloquence has been of little help to states, but eloquence without wisdom has often been a great obstacle and never an advantage." In this popular quotation, Cicero observed a trend that had emerged shortly before his birth, according to which, contrary to the teachings of Socrates and Plato, the Platonist philosopher had not only to be engaged in rhetoric but also to perceive rhetoric as an essential part of philosophy. This convergence of the philosophical and rhetorical traditions in education was apparently "legalised" by Philo of Larissa - the head of the Third or New Academy in 110/109 BC. ' In fact, however, Pierre Hadot correctly emphasised that doing philosophy and producing discourse about philosophy are two aspects, which were carefully differentiated in Ancient Greece. ${ }^{8}$ In the understanding of Socrates and Plato, philosophy as a way of life is that the philosopher inspired pupils and followers to follow him, through his example, his life choice. Such a philosophy had nothing in common not only with Sokrates' traditions, which was producing discourse about philosophy as a way of life but also differed significantly from philosophy in the understanding of Cicero, Antiochus of Ascalon, Apuleius, and others, according to which the philosopher felt an urgent need for rhetoric, with which he convinced his fellow citizens to choose a way of life. ${ }^{9}$ To live as a philosopher, to become a model for others and to convince others to follow a certain way of life, these are completely different philosophies and ways of life.

Plato devoted his theory of education not to the demos, the destructive role of which he realised according to the catastrophic consequences of the Peloponnesian War for the Athens, but to the new caste of rulers-philosophers. Werner Jaeger accurately noted: "The Paideia of the fourth century, after it saw the kingdom of earth blown into dust, fixed its home in the kingdom of heaven. [Jaeger, 1947: 8]. Plato's "Republic" is a book about education that pursues a divine purpose; about the philosopher-rulers who lead the demos to God; about politics in Socrates' view as "the care of the soul"; finally, about the republic as a powerful force that forms the inner world of man.

As you can see, Plato tried to save the Greek civilisation by offering it a difficult but possible format of the new technology of education: continuous and hard individual work on the perfection of the inner world, the ultimate result of which is the achievement of the ideal through knowledge. That is, Plato's "man of faith" as a cultural ideal of man, on the basis of which he wanted to build his "Republic" in the Kingdom of Heaven, was man whose virtues

${ }^{5}$ See [Jaeger, 1947: 160].

${ }^{6}$ See [Cicero, 1860].

${ }^{7}$ In $88 \mathrm{BC}$, during the Mithridatic wars Philo left Athens and took up his residence in Rome, where one of his pupils was Cicero. See [Hadot, 2002].

${ }^{8}$ See [Hadot, 2005].

${ }^{9}$ See [Hadot, 2002]. 
are based on knowledge gained through prolonged and hard work and self-improvement. This format of education required constantly man's self-education, significant internal concentration, renunciation of worldly pleasures, long and laborious work on himself, etc.

\section{Technology of mass imposition of the cultural ideal on the basis of dogmas on the part of state institutions}

New education opportunities were found out and began to be used firstly by the Christian theologians according to Plato's line. It was Origen who in the already proposed by Plato technology for achieving the cultural ideal of "man of faith" introduced two major changes: a) the possibility of achieving an ideal based not on knowledge, but dogmas; b) the necessity for spreading of education among the masses. Essentially, Origen's theory of education is the first use of neuro-programming technology through forming the masses' worldview. Origen's ingenious discovery was that he not only changed the basis of virtues: he replaced knowledge by dogmas, and that on the basis of that new construction he proposed the education technology that, on the one hand, was based on the authoritative ruling class of Plato's paideia-religion, and, on the other hand, was aimed at the education of the masses. That is why already in the early Middle Ages the educational institutions of the Ancient Greeks were closed, and Early Christianity opposed the culture of the masses to a highly rationalised culture of the educated elite [Platonov, 2013].

Two centuries after Origen, Aurelius Augustine finally established a new format for education technology in the Middle Ages and its new goal. From communion to the lofty ideas that enabled man to gain power over himself; from mastering the knowledge and values of high culture, which, as a goal, were considered in the education in Antiquity, Augustine reduced the education goal to "...tracking down the truth through renunciation from the shackles of sensory knowledge to the contemplation of the Divine Essence and the beauty of the world through deepening into oneself, insights of inner knowledge. The latter is revealed through self-examination and renunciation from the sinful sensibility, which avoids the ascent to God as the source of truth and virtue" [Platonov, 2013: 101].

Augustine finally established a new education technology, by which for millennia, up to the present days, Church and State have continuously been improving in practice. We will call it as the technologies of mass imposition of the cultural ideal on the basis of dogmas on the part of state institutions.

The new technology of education did not exclude technology that Plato offered. Rather on the contrary, as Pierre Hadot asserted: “...Christian spiritual exercises appeared only on the grounds, beginning in the second century, to present itself as a philosophy based on the model of the Greek one, that is, as a way of life, including spiritual exercises, borrowed from Greek philosophy" [Hado, 2005: 68]. The Church encouraged continuous and hard individual work on the perfection of the inner world. The difference was in the approaches and its final result: in Plato's view, self-perfection was the work with knowledge that led to the achievement of the ideal on the basis of knowledge, but in Augustine's view, it was the memorization of the doctrinal principles that were not subject to criticism (doubt), and in fact, they were considered the Divine Revelation, which was given to man by God in the already completed form. The education technology, proposed by Plato, set the highest goal before man - the attainment of the Divine, and awakened man's desire to attain it; the theory of education, proposed by Augustine, made society diligently memorize the dogmas established by the Church, as the dominant institution of state and spiritual power at that historical moment. 
Man always received promised gifts for his obedience and diligence: "Then the LORD God took the man and put him into the Garden of Eden to cultivate it and keep it" (Genesis 2:15), Augustine reasoned about it in Book VIII, "The Literal Interpretation of Genesis." 10

According to Augustine, "man of faith", on the basis of which later the Christian theologians according to Plato's line built relationships within the Earthly City as well as between the City of God and the Earthly City, was man whose virtues were based on dogmas imposed by the church, that is, unconscious sets and stereotypes that did not require proof and explanation. Plato's (or rather, Socrates') belief based on knowledge as a way to find God, in Augustine's theory of education it was replaced by faith based on dogmas (just like Plato's understanding of the essence of areté (virtues) and many other things). That is why, in the most famous Plato's work "Republic," the consideration of "Politeia" and "Paideia" takes a central place, while in Augustine's "City of God" that is the most important of his work, two ideas are mainly considered: submission to God and the ruler ("Give to Caesar what is Caesar's, and to God what is God's (Matthew 22:21)), and the struggle against heresies (Coge intrare! $\left.{ }^{11}\right)$.

Researching the problem of the influence of education on society, James Bowen proved that in the $14^{\text {th }}$ century Erasmus of Rotterdam and Martin Luther had already fully utilized the possibilities of education as a tool for preserving and disseminating religious beliefs, that is, as a technology of influence on the development of the society's worldview [Bowen, 2003]. The Inquisition and the Crusades, as a powerful punitive force, taught the Church to use education as a technology by imposing key markers of self-identification on society: the world picture, a philosophy of knowledge, the understanding of one's place at the scales of the Earth and the Universe, the meaning of life, the cultural ideal, values, etc. In general, this allowed the Church Fathers to manipulate public opinion and influence the development of the society' worldview.

\section{Technology, established by the State, for the formation and development of the individual structure, functions and manifestations of the brain in ontogenesis, through the provision of general knowledge and information as services}

A new world picture and new fundamental meanings of Being, connected with the development of Modern philosophy, radically changed the structure and functions of the moulding system in new generations' worldview. New educational institutions replaced episcopal (cathedral), monastic and secular schools and universities in the Middle Ages. Since the $19^{\text {th }}$ century, in the field of education, a number of major reforms were undertaken, which led to the establishment of national education systems, a weakening of the church's influence on the school system, and an increase in educational level. It was during this time that Friedrich Schleiermacher concluded that the philosophy of knowledge "Those who transform the Earth" led to the replacement of faith by reason and the Church by the State. According to Schleiermacher, these cardinal changes led to the fact that the University as a social institution began to mould not servants, but subjects, and education itself focused on the studying process of acquiring knowledge, rather than transferring

\footnotetext{
${ }^{10} \mathrm{https} / / /$ www.ccel.org/contrib/ru/Augustine/part8-11.htm

11 "Compel people to come in" from Luke's Gospel, 14.23-24. The phrase "compelle intrare" is used to conclude that governmental authorities had the right to coerce people into the church.
} 
its products. ${ }^{12}$ Bill Readings revealed the social mission of the University, its historical periods and contemporaneity. He believed that it was the University as a social institution called upon to mould human need for continuous realization of inner creative possibilities, abilities and talents [Readings, 2010].

In the book "Philosophy of Education on the basis of the New Cosmological Concept" published in 2010, in modern educational systems, the author highlighted two conditional models that were to some extent viewed in all modern educational systems: "EuropeanAmerican" and "Soviet". The author examined their characteristics, and also compared the features of their impact on the brain of the younger generations [Bazaluk, 2010]. We can conclude from this analysis that over the past 400 years the third brain neuroprogramming technology was discovered and put into practice. It was preceded by the following discoveries:

Firstly, at the beginning of the $20^{\text {th }}$ century, the abstract nature of Descartes' and Kant's views of "reason", which gave man the possibility to create and transform the world, thanks to the works of Sigmund Freud, Karl Jaspers, Carl Jung, Edmund Husserl and many others, passed into the scientific understanding of the neurobiology of brain, but at the beginning of the $21^{\text {st }}$ century it passed into the development and wide use of neuroprogramming programs. Starting with Dr. Francois Rabelais, a physician and teacher John Locke, a theologian and physician David Hartley, and others, and to Maria Montessori, Lev Vygotsky, Edward Edward Thorndike, Jean Piaget, Abraham Maslow, Carl Ransom Rogers, John Bowlby, Ogden R. Lindsley, Stephen R. Campbell and many others, physicians, psychologists and neuroscientists began to play a major role in the creation and development of the theories of education. The basis of modern theories of education is developed by the achievements in neuroscience and psychology.

Secondly, the Greek understanding of education that meant "deliberately moulding human character in accordance with an ideal," ${ }^{\prime 13}$ as a way of life, was changed. Modern development of theories of education allowed us to paraphrase "deliberately moulding human character" in neuro-programming through precise and consistent impact of the certain educational technologies on the complicating human brain in ontogeny..$^{14}$ Education began to be used as a means of manipulating the complicating human brain as well as micro and macrosocial groups. Moreover, the effectiveness through using educational technologies during throughout ontogenesis was proven, which led to the development of educational technologies aimed at brain neuro programming: from prenatal period until death. ${ }^{15}$

We shall formulate this new technology of neuro-programming as follows: technology, established by the State, for the formation and development of the individual structure, functions and manifestations of the brain in ontogenesis, through the provision of general knowledge and information as services. In general, the open and widely used technology of neuro-programming in the last 400 years is nothing more than the modernized Isocrates' ideas. The rationalism of the Age of Enlightenment has finally supplanted Plato's ideas from the theories of education, transforming education into a public and private business in the

${ }^{12}$ See [Readings, 2010: 110].

${ }^{13}$ The definition of Greek paideia by Werner Jaeger [Jaeger, 1946: xxii].

${ }^{14}$ For example, the works of Burrhus Frederic Skinner, Norman Allison Crowder, Edgar Stones, et al.

${ }^{15}$ For example, the Theories of Educational Neuroscience by Kathryn E. Patten, Stephen R. Campbell, et al.; The Theory of Precision Teaching by Ogden R. Lindsley, Kent Johnson, Elizabeth M. Street, et al.; the studies in andragogy: Eugen Rosenstock-Huessy, Malcolm Shepherd Knowles, and others. 
sphere of economy, and the rising generation into the objects of purposeful or accidental psychological manipulation.

\section{National security}

Thesis of one of the authors, Vasyl Fatkhutdinov [Fatkhutdinov, 2017], is devoted to the issue of national security. New foundations of The European Security Strategy, proposed in the book "The Theory of War and Peace: The Geophilosophy of Europe" by Oleg Bazaluk [Bazaluk, 2017]. The authors came to the conclusion that today there are two main paradigms of the interpretation of national security, according to which it is considered in the context:

1. National interests. ${ }^{16}$

2. Basic values of society. ${ }^{17}$

A security can be defined as the protection and safeguarding of national values from external and internal threats guaranteed by constitutional, legislative and practical system measures. According to the definition, the authors propose to provide such a classification of security in the form of threats to perceived values: external security is the protection of national values and lifestyles from threats coming from outside; internal security, which includes public relations connected with the prevention or elimination of the threat to life and health of people, their property (property) within the country. According to this provision, we can sum up awareness of public and national security as a kind of one common phenomenon. In a way, in our opinion, external security is the essence of national security, but internal is a public safety.

Security is often defined through the "state of defense" formula. ${ }^{18}$ In our opinion, the narrowing of security only to the level of defense leads to the leveling of the concept of security, the degradation of proactive measures related to prevention, timely detection, prediction and influence on factors that can under certain conditions transform into potential threats.

It is necessary make consideration of safety through the category of "condition." For example, security is a condition that provides a sufficient economic and military power of a nation, the ability to counter the threats of its existence, that are coming from other countries and from within its own country. The national security also can be considered as a set of connections and relationships that characterize such a state of a person, social group, society, state, people, which ensures their perseverant and stable coexistence, satisfaction and realization of vital needs, the ability to effectively confront internal and external threats selfdevelopment and progress. ${ }^{19}$

National security has ecological, economic, informational and even humanitarian components, but not all ecological, economic, informational and humanitarian issues can be considered in the context of national security. From our experience, it is inadmissible, for example, to change the content of the state's activities, which is to guarantee the rights and freedoms of citizens, for the sake of supporting a national producer or developing a national language. Obviously, such problems should be solved without the use of extraordinary powers of national security institutions.

Taking into account the above mentioned, we come to the conclusion that national security concerns all aspects of state defense, as well as some issues that belong to other areas of the nation's life. These issues should have the same signs of importance as armed forces.

\footnotetext{
${ }^{16}$ See [Morgenthau \& Thompson, 1985].

${ }^{17}$ See [Wolfers, 1952].

${ }^{18}$ See [Vozzhenikov, 2000].

${ }^{19}$ See [Fatkhutdinov, 2017].
} 
Objects of national security are:

1. A human and citizen: their constitutional rights and freedoms.

2. A society: its spiritual, moral, ethical, cultural, historical, intellectual, material values, information, environment and natural resources.

3. A state: its constitutional system, sovereignty, territorial integrity and inviolability.

\section{Conclusions}

Thus, considering national security as an opportunity to unite citizens around the national idea; the crystallization of national values and awareness of national interests through the prism of balance of interests of the individual, society and the state; the formation of a national identity, we arrive at an understanding of the importance of technology neuro-programming for the national security of any state, region, and the planet in general. By directly influencing the stereotypes of the worldview and setting the behavior of society, neuro-programming technologies essentially form human manifestations on peaceful coexistence or aggression, war.

Thanks to the capabilities of modern technologies of neuro-programming, it is possible to significantly reduce (or, conversely, activate):

1. The threat of encroachment by individual groups and individuals on state sovereignty, territorial integrity, economic, scientific and technical and defense potential of the State, rights and freedoms of citizens.

2. Activities against peace and security of humankind, especially the spread of international terrorism.

3. The threat of terrorist to use of nuclear and other objects in the territory of the State.

4. Attempts to create and operate illegal armed formations, attempts to use the forces of the State's military and law enforcement agencies in the interests of certain forces.

5. Violations by the bodies of state power and bodies of local self-government of the Constitution and laws of the State, human rights and freedoms, of people and citizens, in particular during election campaigns, lack of effective control over compliance with the requirements of the Constitution and the implementation of the laws of the State.

6. Possibility of arising of conflicts in the field of interethnic and interconfessional relations, radicalization and expression of extremism in the activities of certain associations of national minorities and religious communities.

7. The threat of manifestations of separatism in certain regions of the State.

8. Structural and functional misbalance of the political system of society, the inability of individual units to respond promptly to threats to national security.

9. Significant anthropogenic disturbance and technogenic overload of the territory of the State, increase of risks of appearance of man-made and natural emergencies.

\section{[D] References}

Bazaluk, Oleg. Philosophy of Education on Basis of the New Cosmological Concept. Kyiv: Condor, 2010.

Bazaluk, Oleg. The Strategies of Systematization of the Theories of Education. The Main Meaning and Features of the Theories of Education of Plato's and Isocrates' Lines. Future Human Image, Volume 7, 2017: 11-27. 
Bazaluk, Oleg. The Theory of War and Peace: The Geophilosophy of Europe. Cambridge Scholars Publishing, 2017.

Bazaluk, Oleg, and Denys Svyrydenko. Philosophy of War and Peace: In Search of New European Security Strategy. Anthropological Measurements of Philosophical Research, 12, 2017: 89-99.

Bowen, James. A History of Western Education (Volumes 1, 2 and 3). London: Routledge, 2003.

Cicero. De Oratore. Book 3. Translated by J. S. Watson. New York: Harper \& Brothers, 1860. http://pages.pomona.edu/ cmc24747/sources/cic_web/de_or_3.htm

Fatkhutdinov, Vasyl. Administrative and Legal Support of Public Safety in Ukraine. Kyiv: National Academy of Internal Affairs, 2017.

Jaeger, Werner. Paideia: The Ideals of Greek Culture: Volume I: Archaic Greece: The Mind of Athens. Basil Blackwell, Oxford, 1946. https://archive.org/stream/werner-jaeger-paideiathe-ideals-of-greek-culture-vol1\#page/n1/mode/2up

Jaeger, Werner. Paideia: The Ideals of Greek Culture: Volume II: In Search of the Divine Centre. Basil Blackwell, Oxford, 1947. https://archive.org/stream/werner-jaeger-paideiathe-ideals-of-greek-culture-vol2\#page/n1/mode/2up

Hadot, Ilsetraut. Liberal Arts and Philosophy in Ancient Thought. Moscow: Greco-Latin Cabinet by Yu.A. Shichalina, 2002.

Hadot, Pierre. Philosophy as a Way of Life: Conversations with Jeannie Carlier and Arnold I. Davidson. Trans. V. A. Vorobyov. Moscow, St.-Petersburg: Stepnoy veter; Kolo Publ, 2005.

Klepko, Serhiy. Pedagogy of Peace and Philosophy of War: the Search for Truth. Future Human Image, Volume 7, 2014: 46-49.

Morgenthau, Hans and Kenneth Thompson. Politics Among Nations: The Struggle for Power and Peace. $6^{\text {th }}$ edition. New York: McGraw-Hill, 1985.

Plato. Collected Works in Four Volumes. Moscow: Mysl', 1990-1994.

Platonov, Vladimir. Education as a Sociocultural System: the Methodological Problems of the Theory and History of Education. Moscow: "Russian word - uchebnik", 2013.

Readings, Bill. The University in Ruins. Moscow: Publishing House of the State University, 2010.

Ruano, Javier, Dante Galeffi, and Roberto Ponczek. The Constellation of Twinned NGOsSchools: A New Transdemocratic Horizon in the Global Citizenship Education proposed by UNESCO for the Post-2015 Sustainable Development Agenda. Future Human Image, 1 (4), 2014: 110-126.

Vozzhenikov, Anatoly. National Security: Theory, Policy, Strategy. Moscow: Module, 2000.

Wolfers, Arnold. "National Security" as an Ambiguous Symbol. Political Science Quarterly, Vol. 67, No. 4. (Dec., 1952), pp. 481-502. http://files.janjires.webnode.cz/2000000143 cb1e3daba/Arnold $\% 20$ Wolfers $\% 20-\% 20$ National $\% 20$ Security $\% 20$ as $\% 20$ an $\% 20$ Ambiguous\%20Symbol.pdf 